\title{
HONEY, MORE THAN JUST FOOD: THE POSSIBILITY OF APPLICATION IN REGENERATIVE MEDICINE
}

\author{
Jelena M. Živković ${ }^{1}$, Jelena G. Najdanović1
}

\begin{abstract}
Honey has long been recognized as a special natural product, not only because of its nutritional value, but also because of its healing properties. Although it is mostly composed of carbohydrates, it also contains numerous enzymes, amino acids, organic acids, polyphenols, minerals, vitamins and other substances, whose presence varies depending on the type of honey and its botanical and geographical origin. Thanks to its antimicrobial properties, as well as its beneficial effect on wound healing, tissue repair and regeneration, honey could have a potential role in the fields of tissue engineering and regenerative medicine.
\end{abstract}

Acta Medica Medianae 2021;60(4):55-62. engineering

Key words: honey, wound healing, tissue repair, tissue regeneration, tissue

${ }^{1}$ University of Niš, Faculty of Medicine, Department of Biology and Human Genetics, Niš, Serbia

Contact: Jelena M. Živković

81 Dr Zoran Djindjić Blvd., 18000 Niš, Serbia

E-mail: jelena.zivkovic.biologija@medfak.ni.ac.rs

\section{Introduction}

Honey is produced by honey bees (genus Apis) through processing nectar and honeydew (1) using enzymes of their hypopharyngeal glands (2). Nectar honey can be monofloral (from the nectar of one plant type) or polyfloral (obtained from various nectar types). Honeydew honey is obtained by processing plants secretions or excretions of plant-sucking insects. Strictly speaking, pure monofloral honey cannot be obtained, because many other honey plants bloom at the same time as the main plant. Monofloral honey is considered to be one that is obtained mainly from a certain plant and has a characteristic composition and properties $(3,4)$.

Since ancient times, honey has been in human use, primarily as a food. With the development of human civilization, the possibilities of using this natural product expanded, so it began to be used, for example, as a medicine and preservative (5). Such use is based on its antioxidant, antibacterial, antifungal, antiviral, immunomodulatory, wound healing and many other properties $(6,7)$, for which there is growing evidence in the scientific literature.

Injury of any tissue is followed by repair. Tissue repair means that tissue architecture and function are restored after injury through regeneration and replacement processes. Regeneration completely restores damaged tissue to its normal form. Repair of severe tissue injuries or those which are not prone to regeneration ends by filling the injury site with connective tissue and is accompanied by scarring. It is replacement process. Most tissue repair involves both of these processes. Along with tissue repair, it is important to prevent wound infection, which can prolong the healing process and also lead to additional damage not only to injured parts of tissue, but also to healthy surrounding tissue (8). Honey antimicrobial and pro-healing activity, as well as the possibility of preventing scars, makes it a good candidate for use in regenerative medicine (9).

\section{Chemical composition of honey - the main features}

Honey has complex chemical composition and contains a large number of biologically active substances. Richness of honey content is due to its plant origin, but also to the components that bees add to nectar. In honey are found different carbohydrates, enzymes, amino acids, organic acids, polyphenols, minerals, vitamins and many other substances.

The most common compounds in honey are carbohydrates, over $90 \%$ of its dry weight, and they 
are mostly in the form of monosaccharides fructose and glucose. Less common are disaccharides and trisaccharides such as: sucrose, isomaltose, panose, maltotriose, melezitose, erlose, isomaltotriose, isopanose, maltopentaose and others $(10,11)$. The high content of carbohydrates in honey is considered to be the main reason for its high osmolarity (12).

Right after carbohydrates, water is the next most represented honey component ranging from 17 to $20 \%$ (11).

Proteins are also constituents of honey, but are present in much smaller quantities, such about $0.5 \%$. They are mainly in the form of enzymes (such as $\alpha$-amylase, $\beta$-amylase, glucose oxidase, invertase, catalase) and amino acids, whose most common representative is proline, which makes up to $85 \%$ of the total amino acid content. Proteins originate from pollen (primary source) and secretions of bee glands (13-15). Bee antimicrobial peptide, defensin-1, is also honey constituent $(16,17)$. Likewise, another antimicrobial bee-derived peptide named hymenoptaecin can be also found in some honey types (17).

Polyphenols are products of secondary plant metabolism. They can be classified into two groups: flavonoids and non-flavonoids (phenolic acids) (15). The content of these compounds varies among different honeys, so their qualitative content can be used to determine the floral origin of honey (18). Their presence is associated with the honey antioxidant and antimicrobial properties (19).

The main organic acid in honey is gluconic acid. Citric acid, acetic acid, formic acid and many others are represented as well. Organic acids originate from nectar, or are formed from sugars by the action of bee enzymes during honey production (20). Presence of organic acids, primarily gluconic acid, in honey is the main cause of its low $\mathrm{pH}$.

Vitamins and minerals are present in small amounts. Among vitamins, those from B complex and $C$ vitamin are the most common, while among minerals it is primarily potassium, but a whole range of other minerals is represented too. Minerals are also a very stable component of this natural product (14).

The wide range of substances contained in honey gives it special properties that increase its nutritional value, and at the same time are important for human health. The share of these substances in honey is generally not constant, and largely depends on the type of honey and its botanical and geographical origin. Likewise, some compounds contained in honey are subject to changes due to chemical reactions during long-term storage (14).

\section{Antimicrobial effects of honey}

Having in mind the richness and diversity of compounds found in honey, its antimicrobial properties cannot be attributed only to one of them, but to the whole constellation of molecules that give it special antimicrobial characteristics.

Foremost, the $\mathrm{pH}$ value of honey is in between 3.2 and 4.5 , so it represents an acidic environment unfavorable for growth of microorganisms. In addition, high osmolarity of honey, due to its high sugar content, is also one of the factors responsible for its antimicrobial properties $(5,21)$, given that osmotic stress leads to changes that are reflected in depolarization and increased permeability of bacterial cell membrane, as well as reduction in cell size (22). However, a study which compared different natural honeys with culinary processed commercial honey has shown that in the case of the latter there was no antibacterial effect, indicating that this effect is not only conditioned by the honey sugar content (23). In fact, the result of this comparison suggests that not only high osmolarity and low $\mathrm{pH}$ are participating in its antimicrobial effect, but that some other honey compounds have such function.

Hydrogen peroxide is considered to be one of the main honey's constituent that has antimicrobial properties. It arises from glucose as a product of reaction catalyzed with bee-derived enzyme, glucose oxidase (24). In the previously mentioned study, specifically, several different types of honey from various Danish floral sources were examined and their antibacterial activity was compared with culinary processed commercial honey and raw and medical grade Manuka honey $(\mathrm{MH})$. Not only was it found that all honey types had an antibacterial effect, except the commercial one, but also that some of the examined honeys had an even stronger antibacterial effect than $\mathrm{MH}$. Antibacterial action of tested honeys, especially those that had a stronger antibacterial effect, was attributed primarily to the content and activity of hydrogen peroxide (23). Natural role of hydrogen peroxide is in preventing the development of microbes in unripe honey, and after its maturation this role is taken over by a high concentration of sugars, while glucose oxidase is inactivated. This enzyme is reactivated upon honey dilution $(25,26)$. Thus, it is found that binding of enzyme to glucose is much easier in diluted honey, and production of hydrogen peroxide is more continuous, so honey antimicrobial effect is increased (27). The amount of hydrogen peroxide in different honeys varies, and this depends on the type of honey and its dilution $(26,28)$. Although there is, to some extent, a positive correlation between the degree of honey dilution and hydrogen peroxide concentration, hydrogen peroxide activity is highest at $30-50 \%$ honey dilution (26). In fact, the presence of free water molecules in honey is important for maintaining the native conformation and enzymatic activity of the glucose oxidase, as well as the activity of the enzyme catalase. Catalase is an enzyme of pollen origin that participates in destruction of hydrogen peroxide. So, the total amount of hydrogen peroxide in honey also depends on the relationship between actions of these two enzymes (29). There is also synergy between hydrogen peroxide and gluconic acid, which some authors underline as crucial for honey antibacterial activity. It has been shown that these two components lead to bacterial membrane depolarization and destruction of bacterial cell wall in dose-dependent manner (22).

Additionally, polyphenols as the constituents of honey are involved in its antimicrobial action as 
well. These compounds can also contribute in hydrogen peroxide production, as was reported with honeydew honey (30). Polyphenols content varies between honey types. Forest honey (honeydew) is rich in polyphenols. It has more than ten times higher total phenolics and flavonoids contents than acacia honey, as it has been shown in an experiment in which forest honey, polyfloral and monofloral acacia honey from the Šumadija District (Central Serbia) were compared. This investigation has shown that all honey types have antibacterial activity against different bacterial strains, and this activity is most pronounced in forest honey. But forest honey has also shown antifungal activity against some fungal species such as Trichoderma longibrachiatum, Trichoderma harzianum, Penicillium canescens and Penicillium cyclopium (31). Phenolic fractions isolated from 33 Iranian honey samples have shown antimicrobial activity against four bacterial strains: Escherichia coli, Pseudomonas aeruginosa, Staphylococcus aureus and Enterococcus faecalis and this property was attributed not only to honey's individual phenolic compounds but to their joint action (32).

Defensin-1 is a bee-derived antibacterial peptide, which has been found in royal jelly and honey $(17,28)$. The presence and amount of defensin-1 varies strongly and in some types of honey it is completely lacking (33). Mechanism of defensin-1 action is based on bacterial cell membrane permeabilization and then RNA, DNA and protein synthesis inhibition (34). Another antimicrobial peptide, hymenoptaecin, is variable honey component and it is assumed that its presence depends on the microbial pressures in honeybee colonies (17). This antimicrobial peptide forms pores in bacterial envelopes (35).

The antimicrobial activity of $\mathrm{MH}$ is based primarily on the methylglyoxal presence. Methylglyoxal is formed by conversion of dihydroxyacetone, highly present substance in nectar of manuka tree (Leptospermum scoparium) flowers, during honey storage (33). Investigation of the effects of different methylglyoxal dilutions on four bacterial strains (Bacillus subtilis, Staphylococcus aureus, Pseudomonas aeruginosa, and Escherichia coli) has shown that methylglyoxal negatively affects bacterial fimbriae and flagella, damages bacterial cell membrane and causes changes in bacterial cell shape (36).

\section{The application of honey in tissue repair and regeneration}

The use of honey for medicinal purposes has been known since ancient times. Inter alia, many studies suggest that honey has a positive effect on wound healing, tissue repair and regeneration. Acacia honey was used in treatment of excision, incision, burn and dead-space wound models in Swiss Wistar rats of either sex (37). Honey was applied topically and, for that purpose, 5 or $10 \%$ concentration of honey was added to $2 \% \mathrm{w} / \mathrm{w}$ gel sodium alginate gel. The results of this study confirmed that honey treatment aids wound healing by increasing wound epithelization and wound contraction in the excision and burn wound model, breaking strength of the wound in the incision wound model, as well as breaking strength, dry tissue weight, and hydroxyproline content in the dead-space wound model.

Application of honey to the wound site, can serve as a protective coating against infections, mimicking the action of antibiotics. Also, the high sugar content in honey is a good nutritional source for cells at the site of injury (9). Likewise, the high sugar content creates an osmotic pressure that triggers and draws lymph fluid from tissues at the site of application in wound treatment. This supports the process of removing debris and necrotic tissue, which is important at the beginning of tissue repair (16). Mphande and coworkers have investigated whether there was a difference between honey and sugar applied as dressing in wound management of 40 patients. Results of this investigation have shown that honey has greater antibacterial activity than sugar, and is more successful in promoting wound healing (38). Honey can reduce the $\mathrm{pH}$ at the wound site, while stimulating the activity of fibroblasts. The addition of acacia honey to culture media has encouraged migration and differentiation of cultured rabbit corneal fibroblasts. This effect was attributed to the high glucose content in honey, which served as an important source of energy for cells, subsequently to the hydrogen peroxide releasing and lowering the $\mathrm{pH}$ of the medium, which are also factors that can positively affect fibroblast proliferation (39).

Gradual release of hydrogen peroxide from honey applied to the site of injury can be initiated by its dilution with wound exudates. Thus honey, with its antimicrobial action, can prevent wound infection, and at the same time the concentration of hydrogen peroxide is such that it is not toxic to the tissue cells. Also, hydrogen peroxide within physiological range stimulates angiogenesis, a process which is considered as critical for tissue repair $(26,40)$. Namely, blood vessels' network development is an important part of any tissue repair process, since it allows nutrients, cytokines, growth factors, oxygen and many other molecules to reach damaged tissue (4144). Martinotti and colleagues have identified hydrogen peroxide as main honey compound involved in regenerative process. Namely, using in vitro model of immortalized human keratinocyte cell line, they have demonstrated that extracellularly released hydrogen peroxide from honey enters cells through specific aquaporin channels. When found in cytoplasm, hydrogen peroxide facilitates extracellular $\mathrm{Ca}^{2+}$ influx by activating $\mathrm{Ca}^{2+}$-permeable ion channels. An increase in intracellular $\mathrm{Ca}^{2+}$ levels facilitates wound healing, as $\mathrm{Ca}^{2+}$ is essential for activating various cellular-level processes involved in tissue regeneration (45). In order to activate hydrogen peroxide activity, researchers recommend diluting honey before using it as an antiseptic dressing on wounds to an extent appropriate to the presumed amount of fluid that will be released from the wound during treatment (26).

The activity of macrophages, cells whose role in tissue repair is already known, can also be modulated by honey constituents (46). Actually, tissue repair begins with an inflammatory reaction. 
Inflammatory phase lasts up to two weeks, after which it needs to be silenced. Then, through antiinflammatory mediators, synthesis of extracellular matrix and angiogenic process are promoted, which ultimately leads to tissue repair. Main actors of the inflammatory phase are macrophages which, depending on wound conditions, secrete a number of different molecules (47-49). Inflammatory process can be modulated under the influence of honey or its components, through inhibition or stimulation of the synthesis of various cytokines by macrophages and their monocyte precursors (46). Human monocytes exposed to $\mathrm{MH}$ in vitro were stimulated to produce pro-inflammatory cytokines such as interleukin-1 $\beta$ (IL-1 $\beta)$, IL- 6 and tumor necrosis factor- $\alpha$ (TNF- $\alpha$ ) (50). Some authors attribute the stimulatory effect of honey on the inflammatory process to the presence of endotoxins as well (46). On the other hand, the anti-inflammatory effect of honey has also been described and it is attributed primarily to its flavonoid content. Thus, Candiracci and coworkers investigated the effect of a honey flavonoid extract on pro-inflammatory cytokine production by N13 microglia cells pretreated with lipopolysaccharide. Honey flavonoid extract has significantly reduced TNF- $\alpha$ and IL-1 $\beta$ production (51). Given the both proinflammatory and anti-inflammatory effect, it can be altogether said that honey has immunomodulatory properties. Their mechanisms are very complex and conditioned by different honey components, which vary considerably by their presence and quantity, depending on the honey type. Further extensive research is needed in this field, but the assumption is that whether applied honey will have pro-inflammatory or anti-inflammatory effect depends on the wound environment (52).

Defensin-1, in addition to having antimicrobial properties, has also been shown to participate in wound healing process. This peptide in a culture of human keratinocytes promoted secretion of matrix metallopeptidase 9 (MMP-9), cell migration, as well as improved wound closure in vivo (53).

Since the use of honey in superficial wounds treatment has been shown as highly effective, the possibilities of its application in the repair of hard tissues are expanding. Here, the principle of honey action is essentially the same as that on soft tissues, and is largely a result of the action of its numerous components. Honey has been shown to be effective in treating small mandibular bone defects in rats (54). In this study, healing of mandibular defects, filled with sterile honey or untreated, was monitored. According to the presented results, defects' healing process in the experimental group was more significant than in the control group, indicating that honey may support bone healing. Often, in large bone defects' treatment, it is necessary to aid tissue repair with biomaterials, which are frequently on hydroxyapatite base (41-44, 47-49, 55-57). Combining hydroxyapatite with honey, in order to repair the rats' radius bone defects, turned out to be a better solution compared to the independent use of honey or hydroxyapatite (58). Another application in oral surgery was conducted within one small clinical trial, when honey was placed in the socket, immediately after surgical removal of impacted third molars (59). In the honey-treated group, less pain, lower frequency of postoperative complications and less swelling was observed in comparison with the untreated group (control). The effects of honey on cartilage defects repair were also examined. In that purpose, MH, gellan gum (GG) and mesoporous silica-MS composite hydrogels were prepared (60). First, in vitro analysis has shown that these composites had significant changes in peak elastic and dynamic moduli during 45 days of in vitro incubation period with human mesenchymal stem cells. In addition, MS-composite hydrogels ensured good in vitro cytocompatibility and antibacterial activity in a co-culture model, so they were chosen for application in a subcutaneous implantation mice model. In vivo, there was no severe immune response, which means that GG-MH-MS composites represent a very promising tool for cartilage tissue engineering. Honey has the ability to modulate inflammatory cells activity which can actually increase its application as a scaffold additive in the cases of bone infection (61). For example, $\mathrm{MH}$ decreases inflammation and promotes collagen deposition and migration of fibroblast. Therefore, this type of honey can probably promote tissue-material integration/regeneration and accelerate healing of site that surrounds the wound (62-64). Cryogels are biomaterials that have favorable porosity, elasticity and ability to retain three-dimensional architecture, which makes them interesting for application in bone tissue engineering. To overcome the problem of bacterial infection, the application of honey for incorporation into cryogels has attracted a lot of attention recently (65). In the research conducted by Hixon and his team (61), different amounts of $\mathrm{MH}$ were incorporated into cryogel scaffolds made of either gelatin or silk fibroin. Likewise, $\mathrm{MH}$ properties were utilized in a sustained release fashion to help in the bone healing process, while cryogel structure was used as a tissue template. All types of cryogels were examined regarding the effects of $\mathrm{MH}$ on porosity, swelling potential, mechanical durability and cell compatibility. In order to mimic native bone, these scaffolds were mineralized. It was found that a $5 \% \mathrm{MH}$ silk fibroin cryogel had the potential to inhibit bacterial growth while still maintaining adequate porosity, mechanical properties, and cell infiltration. These features are favorable for the application in bone tissue regeneration.

\section{Conclusion}

There are many characteristics of honey, which classify it as a natural product suitable for various medical purposes. In addition to the fact that its price is affordable and that it has an unlimited shelf life, honey has no side effects and is easy to apply to the site of interest. The antimicrobial and wound healing abilities of honey are based on the presence of numerous compounds that give it special characteristics. Application of honey to the site of injury creates a physical barrier between wound and its environment, prevents contamination, and accelerates healing process. Thanks to the antimicrobial properties of honey, its use provides the 
possibility of reducing the utilization of antibiotics during wound healing treatment. In addition to the already proven positive effect on the healing of superficial wounds, its use in the healing of hard tissue defects is being investigated, after independent application or in combination with biomaterials. However, although for now the results of various researches are promising, there are not many scientific papers on the influence of honey in hard tissue repair, and more clinical studies are missing. Despite all mentioned positive effects of honey, some dilemmas remain. One of the issues is the stability of its chemical components during prolonged storage. Likewise, not all mechanisms by which honey influences tissue repair and regeneration through its components have been fully investigated. Also, it is known that there are large differences in the representation of different compounds among honeys, which depend on their type, botanical and geographical origin. Therefore, in order to implement honey in the frameworks of regenerative medicine, it is necessary to standardize its individual components and their effective doses, especially in relation to different tissue types.

References

1. Alvarez-Suarez JM, Gasparrini M, Forbes-Hernández TY, Mazzoni L, Giampieri F. The Composition and Biological Activity of Honey: A Focus on Manuka Honey. Foods 2014;3(3):420-32.

[CrossRef] [PubMed]

2. Kunieda T, Fujiyuki T, Kucharski R, Foret S, Ament SA, Toth $\mathrm{AL}$, et al. Carbohydrate metabolism genes and pathways in insects: insights from the honey bee genome. Insect Mol Biol 2006;15(5):563-76. [CrossRef] [PubMed]

3. Schievano E, Finotello C, Uddin J, Mammi S, Piana L. Objective Definition of Monofloral and Polyfloral Honeys Based on NMR Metabolomic Profiling. J Agric Food Chem 2016;64(18):3645-52. [CrossRef] [PubMed]

4. Martinotti S, Calabrese G, Ranzato E. Honeydew honey: biological effects on skin cells. Mol Cell Biochem 2017;435(1-2):185-92. [CrossRef] [PubMed]

5. Eteraf-Oskouei T, Najafi M. Traditional and modern uses of natural honey in human diseases: a review. Iran J Basic Med Sci 2013;16(6):731-42. [PubMed]

6. Miguel MG, Antunes MD, Faleiro ML. Honey as a Complementary Medicine. Integr Med Insights 2017; 12:1178633717702869. [CrossRef] [PubMed]

7. Ahmed S, Sulaiman SA, Baig AA, Ibrahim M, Liaqat S, Fatima $S$, et al. Honey as a Potential Natural Antioxidant Medicine: An Insight into Its Molecular Mechanisms of Action. Oxid Med Cell Longev 2018: 8367846. [CrossRef] [PubMed]
8. Krafts KP. Tissue repair: The hidden drama. Organogenesis. 2010;6(4):225-33. [CrossRef] [PubMed]

9. Martinotti S, Ranzato E. Honey, Wound Repair and Regenerative Medicine. J Funct Biomater 2018;9(2): 34. [CrossRef] [PubMed]

10. Samarghandian S, Farkhondeh T, Samini F. Honey and Health: A Review of Recent Clinical Research. Pharmacognosy Res 2017;9(2):121-7. [CrossRef] [PubMed]

11. Kamal MA, Klein P. Determination of sugars in honey by liquid chromatography. Saudi J Biol Sci 2011; 18(1):17-21. [CrossRef] [PubMed]

12. Albaridi NA. Antibacterial Potency of Honey. Int J Microbiol 2019:2464507. [CrossRef] [PubMed]

13. Bogdanov $S$, Jurendic $T$, Sieber R, Gallmann P. Honey for nutrition and health: a review. J Am Coll Nutr 2008;27(6):677-89. [CrossRef] [PubMed]

14. da Silva PM, Gauche C, Gonzaga LV, Costa AC, Fett R. Honey: Chemical composition, stability and authenticity. Food Chem 2016;196:309-23. [CrossRef] [PubMed]

15. Cianciosi D, Forbes-Hernández TY, Afrin $S$, Gasparrini M, Reboredo-Rodriguez $\mathrm{P}$, Manna PP, et al. Phenolic Compounds in Honey and Their Associated Health Benefits: A Review. Molecules 2018;23(9):2322. [CrossRef] [PubMed]

16. Oryan A, Alemzadeh E, Moshiri A. Biological properties and therapeutic activities of honey in wound healing: A narrative review and meta-analysis. J Tissue Viability 2016;25(2):98-118. [CrossRef] [PubMed] 
17. Erban T, Shcherbachenko E, Talacko P, Harant K. The Unique Protein Composition of Honey Revealed by Comprehensive Proteomic Analysis: Allergens, Venom-like Proteins, Antibacterial Properties, Royal Jelly Proteins, Serine Proteases, and Their Inhibitors. J Nat Prod 2019;82(5):1217-26. [CrossRef] [PubMed]

18. Anklam E. A review of the analytical methods to determine the geographical and botanical origin of honey. Food Chem 1998;63:549-62. [CrossRef]

19. Pereira DM, Valentão $P$, Pereira JA, Andrade PB. Phenolics: From Chemistry to Biology. Molecules 2009;14(6):2202-11. [CrossRef] [PubMed]

20. Mato I, Huidobro JF, Simal-Lozano J, Sancho MT. Significance of nonaromatic organic acids in honey. ] Food Prot 2003;66(12):2371-6. [CrossRef] [PubMed]

21. Singh V, Pal US, Singh R, Soni N. Honey a sweet approach to alveolar osteitis: a study. Natl J Maxillofac Surg 2014;5(1):31-4. [CrossRef] [PubMed]

22. Masoura M, Passaretti P, Overton TW, Lund PA, Gkatzionis K. Use of a model to understand the synergies underlying the antibacterial mechanism of $\mathrm{H}_{2} \mathrm{O}_{2}$-producing honeys. Sci Rep 2020;10(1):17692. [CrossRef] [PubMed]

23. Matzen RD, Zinck Leth-Espensen J, Jansson T, Nielsen DS, Lund MN, Matzen S. The Antibacterial Effect In Vitro of Honey Derived from Various Danish Flora. Dermatol Res Pract 2018;2018:7021713. [CrossRef]

24. Nolan VC, Harrison J, Cox JAG. Dissecting the Antimicrobial Composition of Honey. Antibiotics (Basel) 2019;8(4):251. [CrossRef] [PubMed] https://www.ncbi.nlm.nih.gov/pmc/articles/PMC69634 15/

25. Schepartz AI, Subers MH. The glucose oxidase of honey. I. Purification and some general properties of the enzyme. Biochim Biophys Acta 1964;85:228-37. [CrossRef] [PubMed]

26. Bang LM, Buntting C, Molan P. The effect of dilution on the rate of hydrogen peroxide production in honey and its implications for wound healing. J Altern Complement Med 2003;9(2):267-73. [CrossRef] [PubMed]

27. Brudzynski K. Effect of hydrogen peroxide on antibacterial activities of Canadian honeys. Can J Microbiol 2006;52(12):1228-37. [CrossRef] [PubMed]

28. Kwakman $P H$, te Velde $A A$, de Boer $L$, Speijer $D$, Vandenbroucke-Grauls CM, Zaat SA. How honey kills bacteria. FASEB J 2010;24(7):2576-82. [CrossRef] [PubMed]

29. Brudzynski K. A current perspective on hydrogen peroxide production in honey. A review. Food Chem 2020;332:127229. [CrossRef] [PubMed]

30. Bucekova M, Buriova M, Pekarik L, Majtan V, Majtan J. Phytochemicals-mediated production of hydrogen peroxide is crucial for high antibacterial activity of honeydew honey. Sci Rep 2018;8(1):9061.

[CrossRef] [PubMed]

31. Srećković NZ, Mihailović VB, Katanić Stanković JS. Physico-chemical, antioxidant and antibacterial properties of three different types of honey from Central Serbia. Kragujevac J Sci 2019;41:53-68.

32. Leyva-Jimenez FJ, Lozano-Sanchez J, Borras-Linares I, Cadiz-Gurrea MDLL, Mahmoodi-Khaledi E, CadizGurrea ML. Potential antimicrobial activity of honey phenolic compounds against Gram positive and Gram negative bacteria. LWT 2019;101:236-45. [CrossRef]

33. Kwakman PH, Zaat SA. Antibacterial components of honey. IUBMB Life. 2012;64(1):48-55. [CrossRef] [PubMed]

34. Ganz T. Defensins: antimicrobial peptides of innate immunity. Nat Rev Immunol 2003;3(9):710-20. [CrossRef] [PubMed]

35. Casteels $P$, Ampe C, Jacobs F, Tempst P. Functional and chemical characterization of Hymenoptaecin, an antibacterial polypeptide that is infection-inducible in the honeybee (Apis mellifera). J Biol Chem 1993; 268(10):7044-54. [PubMed]

36. Rabie E, Serem JC, Oberholzer HM, Gaspar AR, Bester MJ. How methylglyoxal kills bacteria: An ultrastructural study. Ultrastruct Pathol 2016;40(2):10711. [CrossRef] [PubMed]

37. Iftikhar F, Arshad M, Rasheed F, Amraiz D, Anwar $P$, Gulfraz M. Effects of Acacia Honey on Wound Healing in Various Rat Models. Phytother Res 2010;24:583-6. [CrossRef] [PubMed]

38. Mphande AN, Killowe C, Phalira S, Jones HW, Harrison WJ. Effects of honey and sugar dressings on wound healing. J Wound Care 2007;16(7):317-9. [CrossRef] [PubMed]

39. Abd Ghafar N, Ker-Woon C, Hui CK, Mohd Yusof YA, Wan Ngah WZ. Acacia honey accelerates in vitro corneal ulcer wound healing model. BMC Complement Altern Med. 2016;16:259. [CrossRef] [PubMed]

40. Cho M, Hunt TK, Hussain MZ. Hydrogen peroxide stimulates macrophage vascular endothelial growth factor release. Am J Physiol Heart Circ Physiol. 2001. 280(5):H2357-63. [CrossRef] [PubMed]

41. Najdanović J Cvetković V, Vukelić-Nikolić $M$, Stojanović S, Zivković J, et al. Vasculogenic potential of adipose-derived mesenchymal stem cells in vitro induced into osteoblasts applied with platelet-rich plasma in an ectopic osteogenic model. Acta med Median. 2019;58(4):57-65.

42. Najdanović J, Cvetković $V$, Stojanović $S$, VukelićNikolić M, Stanisavljević M, Živković JM, et al. The Influence of Adipose-Derived Stem Cells Induced into Endothelial Cells on Ectopic Vasculogenesis and Osteogenesis. Cel Mol Bioeng 2015;8:577-90. [CrossRef]

43. Najdanović JG, Cvetković VJ, Stojanović S, VukelićNikolić MĐ, Čakić-Milošević MM, Živković J M, et al. Effects of bone tissue engineering triad components on vascularization process: comparative gene expression and histological evaluation in an ectopic bone-forming model. Biotechnol Biotechnol Equip 2016;30(6):1122-31. [CrossRef]

44. Živković JM, Vukelić-Nikolić MĐ, Najdanović JG, Stojanović S, Vitorović JS, Radenković MB, et al. Bone tissue engineering based on bone marrow in blood clot loaded on mineral matrix carrier: Experimental study in subcutaneous mice model. Acta med Median 2017; 56(3):5-11.

45. Martinotti S, Laforenza U, Patrone M, Moccia F, Ranzato E. Honey-Mediated Wound Healing: $\mathrm{H}_{2} \mathrm{O}_{2}$ Entry through AQP3 Determines Extracellular $\mathrm{Ca}^{2+}$ Influx. Int J Mol Sci 2019;20(3):764.

[CrossRef] [PubMed]

46. Majtan J. Honey: an immunomodulator in wound healing. Wound Repair Regen. 2014;22(2):187-92. [CrossRef] [PubMed]

47. Živković JM, Stojanović ST, Vukelić-Nikolić MĐ, Radenković MB, Najdanović JG, Ćirić $M$, et al. Macrophages' contribution to ectopic osteogenesis in combination with blood clot and bone substitute: possibility for application in bone regeneration strategies. Int Orthop 2021;45(4):1087-95. [CrossRef] [PubMed]

48. Živković JM, Najman SJ, Vukelić MĐ, Stojanović S, Aleksić MV, Stanisavljević MN, et al. Osteogenic effect of inflammatory macrophages loaded onto mineral bone substitute in subcutaneous implant. Arch Biol Sci, Belgrade 2015;67(1):173-86. [CrossRef]

49. Živković JM, Najman SJ, Stojanović S, Najdanović JG. Interactions between skeletal system and macrophages in homeostasis and bone injury. FU Med Biol 2016;18(1):6-11. 
50. Tonks AJ, Cooper RA, Jones KP, Blair S, Parton J, Tonks A. Honey stimulates inflammatory cytokine production from monocytes. Cytokine 2003;21(5): 242-7. [CrossRef] [PubMed]

51. Candiracci M, Piatti E, Dominguez-Barragán M, GarcíaAntrás D, Morgado B, Ruano D, et al. Anti-inflammatory activity of a honey flavonoid extract on lipopolysaccharide-activated N13 microglial cells. J Agric Food Chem 2012;60(50):12304-11. [CrossRef] [PubMed]

52. Martinotti S, Bucekova M, Majtan J, Ranzato E. Honey: An Effective Regenerative Medicine Product in Wound Management. Curr Med Chem 2019;26(27):5230-40. [CrossRef] [PubMed]

53. Bucekova M, Sojka M, Valachova I, Martinotti S, Ranzato E, Szep Z, et al. Bee-derived antibacterial peptide, defensin-1, promotes wound re-epithelialisation in vitro and in vivo. Sci Rep. 2017;7(1):7340. [CrossRef] [PubMed]

54. Hajizadeh F, Derakhshan B, Peimani A, Abbasi Z. Effect of Topical Honey on Mandibular Bone Defect Healing in Rats. J Contemp Dent Pract. 2018;19(1): 47-51. [CrossRef] [PubMed]

55. Vukelić-Nikolić MĐ, Najman SJ, Vasiljević PJ, JevtovićStoimenov TM, Cvetković VJ, Andrejev MN, et al. Osteogenic capacity of diluted platelet-rich plasma in ectopic bone-forming model: Benefits for bone regeneration. J Craniomaxillofac Surg. 2018;46(11): 1911-8. [CrossRef] [PubMed]

56. Najman SJ, Cvetković VJ, Najdanović JG, Stojanović S, Vukelić-Nikolić MĐ, Vučković I, et al. Ectopic osteogenic capacity of freshly isolated adipose-derived stromal vascular fraction cells supported with plateletrich plasma: A simulation of intraoperative procedure. J Craniomaxillofac Surg 2016;44(10):1750-60.

[CrossRef] [PubMed] https://www.sciencedirect.com/science/article/pii/S10 10518216301792?via\%3Dihub

57. Cvetković VJ, Najdanović JG, Vukelić-Nikolić MĐ, Stojanović S, Najman SJ. Osteogenic potential of in vitro osteo-induced adipose-derived mesenchymal stem cells combined with platelet-rich plasma in an ectopic model. Int Orthop 2015;39(11):2173-80.

[CrossRef] [PubMed]

58. Bigham-Sadegh A, Karimi I, Hoseini F, Oryan A, Sharifi S, Pakzad A. Effects of Honey and Hydroxyapatite on Bone Healing in Rats. Trauma Monthly 2018;23(4). [CrossRef]

59. Elbagoury EF, Fayed NA. Application of "natural honey" after surgical removal of impacted third molar. Egypt Dent J 1985;31(3):203-11. [PubMed]

60. Bonifacio MA, Cochis A, Cometa S, Scalzone A, Gentile P, Procino G, Milano S, Scalia AC, Rimondini L, De Giglio $E$. Advances in cartilage repair: The influence of inorganic clays to improve mechanical and healing properties of antibacterial Gellan gum-Manuka honey hydrogels. Mater Sci Eng C Mater Biol Appl 2020;108: 110444. [CrossRef] [PubMed]

61. Hixon KR, Lu T, Carletta MN, McBride-Gagyi SH, Janowiak BE, Sell SA. A preliminary in vitro evaluation of the bioactive potential of cryogel scaffolds incorporated with Manuka honey for the treatment of chronic bone infections. J Biomed Mater Res B Appl Biomater 2018;106(5):1918-33. [CrossRef] [PubMed]

62. Leong AG, Herst PM, Harper JL. Indigenous New Zealand honeys exhibit multiple anti-inflammatory activities. Innate Immun 2012;18(3):459-66. [CrossRef] [PubMed]

63. Ranzato E, Martinotti S, Burlando B. Epithelial mesenchymal transition traits in honey-driven keratinocyte wound healing: comparison among different honeys. Wound Repair Regen 2012;20(5):778-85. [CrossRef] [PubMed]

64. Sell SA, Wolfe PS, Spence AJ, Rodriguez IA, McCool JM, Petrella RL, Garg K, Ericksen JJ, Bowlin GL. A preliminary study on the potential of manuka honey and platelet-rich plasma in wound healing. Int J Biomater 2012;2012:313781. [CrossRef] [PubMed]

65. Minden-Birkenmaier BA, Bowlin GL. Honey-Based Templates in Wound Healing and Tissue Engineering. Bioengineering 2018;5:46. [CrossRef] [PubMed] 


\title{
MED, VIŠE OD HRANE: MOGUĆNOST PRIMENE U REGENERATIVNOJ MEDICINI
}

\author{
Jelena M. Živković ${ }^{1}$, Jelena G. Najdanović ${ }^{1}$ \\ ${ }^{1}$ Univerzitet u Nišu, Medicinski fakultet, Institut za biologiju i humanu genetiku, Niš, Srbija \\ Kontakt: Jelena M. Živković \\ Bulevar dr Zorana Đinđića 81, 18000 Niš, Srbija \\ E-mail: jelena.zivkovic.biologija@medfak.ni.ac.rs \\ Med je od davnina prepoznat kao dragoceni prirodni produkt, ne samo zbog svoje \\ nutritivne vrednosti, već i zbog svojih lekovitih svojstava. Iako je u najvećoj meri sačinjen od \\ ugljenih hidrata, on sadrži i brojne enzime, aminokiseline, organske kiseline, polifenole, \\ minerale, vitamine i druge supstance, čija zastupljenost varira u zavisnosti od vrste meda i \\ njegovog botaničkog i geografskog porekla. Zahvaljujući svojim antimikrobnim svojstvima, \\ kao i blagotvornom efektu na zarastanje rana, reparaciju i regeneraciju tkiva, med može imati \\ potencijalnu ulogu u oblastima tkivnog inženjerstva i regenerativne medicine.
}

Acta Medica Medianae 2021;60(4):55-62.

Ključne reči: med, zarastanje rana, reparacija tkiva, regeneracija tkiva, tkivno inženjerstvo 